\title{
Powerful and Powerless Language Usage Between Genders: A Case Study Among Lecturers
}

\section{Mohd Nur Fitri Bin Mohd Salim¹, Asmahanim Binti Haji Mohamad Yusuf ${ }^{1}$, Wan Zumusni Binti Wan Mustapha", Irma Binti Ahmad¹, and Mohamad Safwat Ashahri Bin Mohd Salim²}

${ }^{1}$ Academy of Language Studies, Universiti Teknologi MARA (UiTM) Negeri Sembilan, Seremban Campus, Seremban 3, Negeri Sembilan, Malaysia

${ }^{2}$ Academy of Language Studies, Universiti Teknologi MARA (UiTM) Tapah Campus, Perak, Malaysia

\section{Abstract}

This study investigates the gender language used in workplace; specifically, on the comparison and exploration of power language between male and female lecturers who are teaching in the education field. In the effort to answer whether the general opinion that man includes more power language in their speech compared to woman;

Corresponding Author: Mohd Nur Fitri Bin Mohd Salim fitrisalim@uitm.edu.my

Received: 1 July 2019

Accepted: 18 July 2019

Published: 31 July 2019

Publishing services provided by Knowledge

(c) Mohd Nur Fitri Bin Mohd Salim et al. This article is distributed under the terms of the Creative Commons

Attribution License, which permits unrestricted use and redistribution provided that the original author and source are credited.

Selection and Peer-review under the responsibility of the AICLL 2019 Conference Committee. equal numbers of participants are chosen from both genders and several observations of teaching and learning sessions initiated by the participants in their respective classes were conducted by the researchers. The language used by all participants was analyzed based on the use of two language expressions; directives and elicitations. The results of the findings suggest that male lecturers used more directives and elicitations; with Male Lecturer A, who used a total of $27 \%$ power languages and Male Lecturer B, who used a total of $35 \%$ power languages. The power language used by the female lecturers are relatively less than male lecturers; with both female lecturers: Female Lecturer A and B each using a total of 19\% power languages in their speech. Therefore, the study shows that male uses more power language than women. However, this study also indicates that the use of their power language also depends on the context of their language usage.

Keywords: powerful language, powerless language, gender language, dominance theory, interactive positioning

\section{Introduction}

Traditional view of men and women had manifestly discriminated that they belonged to different spheres of public domain. Hall had stated that in the traditional worldview, men were firmly placed in the defined public world of business, commerce and politics and women were placed in a private world of home and family. In such ambiance, men 
or view has become more and more irrelevant after the Women's Movement in 1960's as more and more women involved in the working world which has perpetually change the general image of women society until today (p.2). Moreover, the issue of common power has been brought up in different domains where language is used as a tool to attain a powerful stand in decision making and to attain control; in both workplace and household (Abdullah Yusoff, 2010). Therefore, in this paper, researcher has chosen workplace domain; higher education institution, as a context for them to explore the use of powerful language between male and female lecturers, to compare of powerful language used by both gender and relation of both factors with context of classroom lesson.

\section{Literature Review}

Rangkuti and Lubis (2018) elaborated on the use of language as a reflection of personality and user. Power language is communicating with influence, authority and confidence. These three elements can be seen in an individual's manner of speaking. The absence of "Umm", "I mean", "I guess" and etcetera in an individual's speech shows that a person is not in hesitant whereas it demonstrates persuasion. O'Barr stated that regular use of speech markers like nonverbal hesitations, verbal hesitations, deictic phrases, formal language, tag questions, hedges and intensifiers displays 'powerless' language (O'Barr, 1982 cited Areni and Sparks, 2005).

Apart from speech markers, power language is also about how competent, knowledgeable and familiar a person is of the subject or information conveyed. This is also related to, as stated by McGinty (2001); that a person directs than responds, make statements, contextualizes with authority, contradicts, argues and disagrees, and lastly, practices effect of control.

Women and men are brought up differently with the similar but distinct cultures which influences how they speak and how men and women speak with each other. Both genders engage in a cross cultural communication when they speak to each other (Henley and Kramarae; Maltz and Borker; Tannen as cited in Herrick, 1999). Consequently, the difference between both genders transpires in a way that men are seen as more confident and more assertive than women.

Women traditionally speak by using hedges, indirectness and tag questions to maintain social relationship, composure and poise (Lakoff, 1975 cited Herrick, 1999). These speech markers show just how women have less confidence and are unsure of their own selves. When women speak with authority, they are looked at as unfeminine 
but if women talk as what is expected on how women should talk, they are seen as incompetent and unconfident (Koonce, 1997).

On the other hand, using tag questions does not mean that a person is powerless or unconfident. Tag questions can also be used by a person of power and status as it is used for elicitation and to control the message recipient provides and these actions can be seen in doctors and lawyers. A study done by Harris (1985) found that lawyers and judges were inclined in using questions to summarize, confirm information and to show control over others (Blankenship \& Craig, 2007).

The use of tag questions depends on the context as it may show that a person's information may be from a non-credible source hence shows lack of knowledge, confidence and belief that the information is correct. The degree of a person's ability to persuasion is linked with tag questions and hedges.(Areni and Sparks, 2005; Blankenship and Craig, 2007). The Elaboration Likelihood Model (ELM) shows that persuasion can occur several ways; as a peripheral cue, as an elaboration enhance and as elaboration inhibitor. It also functions as a biasing influence on argument processing and as a relevant argument. (Areni \& Sparks, 2005).

Webb (2012) discussed that the power of discourse usage refers to the "control" put upon non-powerful participants of communication by those who are dominating the interaction (Fairclough, 2001). The influence of assumption and generalization that; males are more superior and dominant compared to females raises the questions on what are influences of male dominance in their language use pattern. Uchida (1992) referred to the Difference Theory which stated that even though men and women are living together socially, they belong to "different and separate cultural worlds" thus promotes the difference in ways of speaking between them (as cited in Nemeti \& Bayer, 2007). Hence, the basis of power language usage among men is highly initiated by the cultural and societal influences and expectations.

Robinson, Frost, Buccigrossi and Pfeffer (2003) stated that the connection between gender status and language would show the outcome that males are dominant in almost all aspects of life. This has also influenced the use of power language among men whereby according to Holmes (2005); the ways men use their discourse styles are based on "speaking with authority", as what has mentioned by Pearson et. al (1991). The authoritative qualities in language used by men indicate a higher degree of power language usage among them compared to women.

Nemeti and Bayer (2007) related the dominance of males in their language use with the Dominance Theory which stated that men and women are living in a world that has unequal distribution of power and status; whereby more focus of power is put 
upon male dominance and gender division. Holmes (2005) had further stressed on the basics on language usage among men which are mainly associated with authority and leadership; thus, indicating the expectations of the society in regarding men as the leader. Therefore, in interpreting these expectations into their language use; the usage of power language is expected to be higher in serving their role to lead in the society.

Saul (2010) even suggested that the power language used by male, which is generally regarded as more significant compared to female; had not just given them the ability to shape the thoughts put by the society upon them, but it also gives men the ability to shape the reality. This is further supported through Spender (1985:143) (as cited in Saul, 2010) who argues that men are able to shape reality through the use of their language due to the fact that "categorizations of reality depends on our social perspective" and in a society which accepts man as more dominant then woman; their usage of language is said to be more significant and powerful.

In the workplace, the act of being direct shows dominance and the issue of being direct and the use of directives is related with empowerment of a person in the office. There was a study done by Pufahlbax (1986) on directives and he studied staff interaction in the workplace of a University. What she found is that in staff meetings and it was found that the way they interact in the office reflect the way they interact socially as well. Furthermore, the interaction in and out of the office plays a noticeable role (Vine, 2004).

In the office, men and women interact differently. Men look at conversation as making negotiations while women tend to communicate to connect with other people, finding common grounds, build connection and intimacy (Tannen, 1994). When working in the office, most women lack confidence. It can be seen in the way of giving orders and men and women have a different way of giving orders.

Sheriden (2007) said that men have a more direct way in giving orders and women, the opposite. The demand and statements given by women are softer (Coates, 1989; Tannen, 1996; Spender, 1980; Case, 1994; as cited in Sheriden, 2007). McGinty states that to show power, let's say in a meeting, a person needs to be straight to the point, direct, precise, at most importantly being able to hold the listener's attention (McGinty, 2007). Sheridan's study which consists of both genders showed that women are longer winded when speaking in a meeting compared to men. Plus, a male face to face meeting shows a much more balanced use of hedges and questions, with a far higher use of tagged questions compared to the females in the office (Sheriden, 2007) This indicates that men tend to me more confident and conviction when speaking hence the language used are more in power. 
Holmes (2005) described one of teacher's roles is as a leader which initiate mentoring and leadership talk in order to develop interactive learning with the students. Therefore, the teaching and learning process between a lecturer and students in the classroom depends on the ability of the lecturer to trigger students' response on the topics or issues that they are learning in order to create two-way communication between them. Newman et al (2008) discussed on the issues raised by Mulac, Seibold and Farris (2000) who found that men are more likely to initiate interaction through questions, offer compliments, apologies and opinions. Relating this with the interaction of both genders in the teaching profession; these strategies in initiating interactions and the different level of usage between male and female lecturers would certainly indicate a different level of power language used in their speech.

Newman (2008) also raised the same issue mentioned by O'Barr (1982, as cited Areni and Sparks, 2005) by identifying women as the ones who use "powerless language" such as hedges and tag questions. The use of this "powerless" language among female lecturers might be the early indications that the use of power language is greater among male lecturers compared to the females. In addition, considering the role of lecturers as leaders of interactions in the classroom; Holmes (2005) has further discussed that male's speech is influenced by masculine conception; the conception of male's masculine linguistic features is an ideal factor which creates an effective leader. This gives more opportunity for male lecturers to practice power language in interacting with the students compared to female lecturers who would have to adapt in the same conception in order to maximize their use of power language.

The reasons which create the different level of power language usage between male and female lecturers might also be the result of the different context of speech preferred by each of the gender, as suggested by Coates (1988; as cited in Michael et al, 2010). The preference of male to speak in a referentially-oriented talk in public compared to female who prefer to speak in an intimate affective-oriented talk; also promotes the dominance among male lecturers to use more power language in their effort to initiate talk in their preferred surrounding. In other words, male lecturers are more comfortable to use power language due to the use of the language in their preferred usage context.

\section{Research Method}

The framework for power language used in this study was based on gender and grounded on Searle (1976) and Xu (2009). To explain the Power language, this study used two language expressions: 
1. Directives: Expression used by speaker to get hearer to do something

2. Elicitations: Expression by speaker that requires hearers to say something.

The use of both language expressions by both genders will be identified, counted and compared.The second study is on Positioning Theory (Harre and Van Lagenhove, 1999; as cited in Bogum, 2008). There are two aspects in this theory; the lecturers Reflexive and Interactive Positioning. This study only focuses on the lecturers' Interactive Positioning. Interactive Positioning focuses on how the lecturers' used of power language affects the students' responses in class. These two studies have enabled the researchers to get to know the power language used by the lecturers in classroom, the difference of power language used between male and female lecturers and lastly to explore the relation between the teachers' used of power language with their gender, and the context where power language is used.Population of this study is male and female lecturers in faculty of education. Two attain closer understanding on the difference of power language used by both gender, a case study was conducted and purposive sampling method were used. The sample were two male and two female lecturers from the faculty of education. The instrument used in this study was recording. Consent was asked from each lecturer for their class lecture to be recorded. The first 30 minutes of class lecture by each lecturer was recorded.

In this study, both quantitative and qualitative data analysis methods were used. In the first phase, power language used by both male and female lecturers was determined. The recordings were transcribed and the contents in the transcripts were then analyzed. The frequency of power language used; elicitations and directives, by all male and female lecturers were determined and presented in a table. The findings will show the difference in frequency of power language used based on gender and context.

In the second phase, Thematic Discourse Analysis (Weber, 1990 in Lovorn et. al., 2012) was used to analyze the transcripts. Weber explained that the content of the transcripts should be coded and grouped under different themes. He further explained that once agreement was reached among the researches, categories were tight enough to maximize exclusivity for each theme. The themes at this phase were based on the research objectives; to determine the use of power language between male and female lecturers in public universities and to compare the use of power language between male and female lecturers in faculty of education. In the final phase, Positioning theory was used as the basis for the analysis. As mentioned earlier, there are two aspects in this theory; the teachers Reflexive and Interactive Positioning. This study only focuses on the lecturers Interactive Positioning which focuses on how the lecturers' used of power language affects the students' responses in class. The analysis method used was 
thematic discourse analysis. This is to answer the last research objective; to explore the relation between the lecturers' used of power language with their gender and the context where power language is used.

\section{Result and Discussion}

Table below shows the total frequency of power language used by 2 male and 2 female lecturers in a 30-minute lecture for each lecturer.

Types of power language
Lecturers
Female Lecturer A
Female Lecturer B
Male Lecturer A
Male Lecturer B
Total

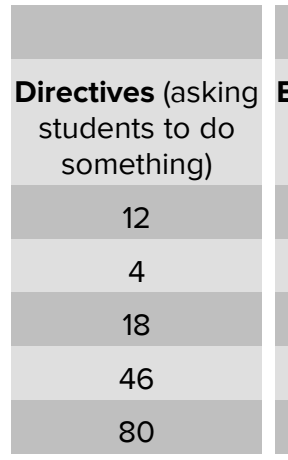

\begin{tabular}{|c|} 
Elicitation (Asking \\
students to say \\
something) \\
28 \\
35 \\
39 \\
26 \\
128
\end{tabular}

\begin{tabular}{|c|}
\hline $\begin{array}{c}\text { Total number of } \\
\text { power language } \\
\text { used }\end{array}$ \\
\hline 40 \\
39 \\
57 \\
72 \\
\hline 208 \\
\hline
\end{tabular}

\subsection{Frequency based on gender}

The table shows that male lecturers had used power language more frequently than the female lecturers in this case study, with the frequency of 64 out of 80 (80\%) for the use of directives and 65 out of 128 (50.8\%) for the use of elicitation. From the overall frequency, it can be seen that male lecturers have used more power language than female lecturers with frequency of 129 out of 208 which constitute $62 \%$ of the power language used by all lecturers in this study.

\subsection{Frequency based on classroom context}

From the table, it can be seen that the highest frequency of power language used is shown by Male Lecturer A with total frequency of 72 out of 208 (35\%), The subject taught by the lecturer was Research Methodology: Statistics. The class session was meant to discuss and facilitate the progress of the students' group project. This is followed by Male Lecturer A, with frequency of 57 out of 208 (27\%). The subject taught by the lecturer was Practices and Reflection in TESL. The class session was meant to discuss on the topic of topic of ESL assessment and to check on students' progress in their case study. The lowest frequency is shown by Female Lecturer B with frequency 
of 39 (19\%). The subject taught by the lecturer was English for Academic Purposes. The lesson was meant for reading comprehension lesson which involved discussion on the topic and the text chosen. The frequency of power language used by Female Lecturer A has shown close number of frequencies; 40 out of 208 which provide similar percentage of power language used with Female Lecturer B; $19 \%$.

\subsection{Differences between genders}

The findings indicated that the male participants use more power language than the female participants. However, differences are observed and identified between participants of the same gender as well. For example, Male Lecturer $B$ tends to use more directives while Male Lecturer A used more elicitations in his conversation with the students. From the observation, researchers found that Male Lecturer B was more comfortable being authoritative in his pedagogical instruction, thus indicating that he has more control over the classroom and was able to get the listener to oblige better, $\mathrm{Xu}$ (2009) discussed on the same issue, stating that the use of directives aim to drive the listener to compel to a certain action, physically or verbally, thus suggesting the power of controlling. However, Male Lecturer A declined to use his power language in the same authoritative manner by using more elicitations in his speech, asking opinions and negotiating feedbacks with the students. Therefore, the result of this study rejects the general opinion as suggested by Pearson et al (1991) who stated that men "speak with authority" (as cited in Holmes, 2005).

Even without "speaking with authority", Male Lecturer A is also very much in control of his class. He controlled his class with the use of elicitation, which requires the students to verbally respond to the lecturer and this finding is in line with Sinclair and Coulthard (1975, as cited in Xu, 2009). This shows that by initiating students' verbal response through elicitation, lecturers could also be able to maintain an obedient classroom as how initiating physical response would do. In fact, the use of elicitations was able to promote a more interactive atmosphere in the classroom through increased students' verbal responses.

The observation conducted in this study had also further emphasized Lakoff's (1975) theory which suggested that women use more hedges and tag questions in their speech compared to men, as discussed by Romaine (2003). This influence their use of power language as the use of hedges and tag questions are usually associated with 'powerless language, as discussed by Newman (2008) and suggested by O'Bar (1982). However, focusing on what has been discussed by Holmes (1990) who agreed that the use of tag 
questions and hedges that occur frequently in women speeches indicates the sense of responsibility to produce a successful interaction (Johnson, 1980, p. 72; Holmes, 1984b; Cameron et al., 1988). Considering that women focus more on building connections rather than negotiating interactions (Tannen, 1994), the use of hedges and tag questions among female participants in this study could also be interpreted as a way for them to create a better understanding with their students. Lakoff explains this issue from the same perspective when he suggested that use of women's conversational speech that includes the use of hedges, indirectness and tag questions are means to maintain the social relationship built between them and the listeners (as cited in Herrick, 1999).

\subsection{Power language usage among lecturers}

The context of interactions which took place in their different respective surrounding could influence the level of power language used by each lecturer in the study. Newman (2008) emphasized on matter; stating that different interaction and responds received from students led towards different results of language usage between genders, including the use of power language. This is shown when Female Lecturer A reflected using more directives through phrase such as, "Can someone share your time division", after she saw that there were no students volunteering to share their assignment and when Male Lecturer A used more elicitations in his speech in order to stimulate students verbal responses by asking question such as; "any question so far?" This may also apply to other contexts of power language when it is being analyzed in from the different influences of; subject matter taught in the classroom and the level of classroom proficiency with the subject matter.

The observation conducted in this study also reflects the similar research by Tannen (1994) who discussed on the influence of conversation contexts in language usage among genders in the workplace. He suggested that male tends to focus more negotiations in their conversation while female's focus is more on building connections with listeners. From the observations, male participants tend to use negotiation phrases; such as when Male Lecturer A negotiated assignment progress using phrase; "When do you plan to do it?" and agreed with students' answer with; "Oh, during the break" instead of assigning specific date for assignment dateline right away. This tendency to use negotiation influences the usage of elicitations thus increasing the usage of power language. The same rule applies to Male Lecturer B who uses more directives in his use of power language while negotiating with students through phrases such as, "You must define the scale, the order. Look also at the rank of each scale, okay?" 
Focusing on the listeners as one of the contexts which influence the usage of one's power language; this study found out that the type of listeners and feedbacks that they provide towards participants' effort to communicate influence the frequency of power language used by the participants. The 'conversational classroom', as mentioned by Waite et al (2003); explains the lecturers' effort to be closer to the students (as cited in Bar, Tews \& Robling, 2005) thus influencing the type of power language used in classroom. This is evident in terms of frequencies of elicitations used by all of the participants which is higher than directives, indicating that the lecturers are trying to maintain a friendly classroom environment where the students, who are young adult learners; have opportunity to voice their opinion and concern. Such condition might differ if the listeners are from a different context of audience altogether, such as school students.

\subsection{Interactive positioning}

Relating the use of power language among the lecturers with the theory of interactive positioning; both groups of male and female lecturers strategized their use of power language through the feedbacks gained from the students when they are implementing elicitations as their language expression. All lecturers seem to be able to capitalize and make full use of elicitations in order to initiate interactive communication with the students thus making the lesson more meaningful for the learners. For example, Female Lecturer A often gave opportunities for students to interrupt his explanation by asking random questions such as "what should you do then when you went blank and do not know how to proceed?" While based on Male Lecturer A's speech in his classroom; he provided opportunities for students to contribute to his storyline or explanation content by asking, "Those who have worked in universities under MARA, some of you are working in MSU or other private colleagues; what is your experience in testing at the faculty level?"

Even though feedbacks gained from students are not as rapid as what he expected, he continued using the method and towards the end of the class more and more students are participating in the discussion. In other words, Male Lecturer A has succeeded in positioning the students to interact in the classroom by using his power language. Moreover, he has also succeeded, through his choice of power language; implement meaningful learning for the students.

Harré et. al. (2004) discussed on the conditions of meaningfulness in interaction through Positioning Theory whereby those who are given the task to correspond with 
the speaker are given the chance to "take charge" in the conversation. The same methodology was applied by all of the lecturers through elicitation; when they gave the chance to the students to "take charge" in the process of teaching and learning by corresponding with feedbacks which would change the topic or subject of discussion in the classroom. Therefore, opportunities are given to the students to participate and make their learning experience better when they are positioned to take part and control the classroom discussions interactively.

Specifying on the language expressions used by the lecturers, the result showed that even though the use of elicitations is almost equal among all of the lecturers who participated in this study, there is a gap of difference when it comes to the usage of directives between the male and female lecturers. Cowie (2000) discussed about the tendency for male speakers to demonstrate competitiveness in their speech; thus, providing insights that the male participants of this study might have the tendency to portray their gender identity through their speech; by instructing students and expecting them to follow the instructions they gave. Cowie later cited Spender (1980) and Coetes (1986) who discussed on the preference of male in dominating and silencing others in their speech. Thus, portraying the basis power and dominance as the reason why male lecturers opted to use more directives in their power language compared to the female lecturers.

\section{Conclusion}

From this study, it was found that man uses more power language than woman. However, this does not indicate that female language in this context is powerless because the use of power language is closely related to the perspective of classroom lesson. Further investigation on different classroom contexts would also be beneficial as to have a well-defined picture on power language of similar background. In contrast, research on lecturers' use of power language of the same subjects and the same classroom context would also help in recognizing and understanding the use of power language between male and female lecturers. However, aspects other than the classroom can also be looked at as power language usage between male and female in the workplace should also be studied in the office environment as alternatively, the observation could be between the relations and communications of power language between male and female colleagues. 


\section{References}

[1] Abdullah Yusoff, S. (2010). Household decision making and expenditure patterns of married men and women in Malaysia. Journal of Family and Economic Issues, 31(3), 371-381.

[2] Areni, C. S., \& Sparks, J. R. (2005). Language power and persuasion. Psychology and Marketing, 22(6), 507-525.

[3] Blankenship, K,L., \& Craig T.Y. (2005) Language and persuasion: tag questions as powerless speech or as interpret in context. Journal of Experimental Social Psychology, 34(1), 112-118.

[4] Bogum, Y. (2008). Uninvited guests: the influence of teachers' roles and pedagogies on the positioning of English language learners in the regular classroom. American Educational Research Journal, 45(2), 495-522.

[5] Bars, H., Tews, E., \& Robling, G. (2005). Improving feedback and classroom interaction using mobile phones. Proceedings of the IADIS International Conference on Mobile Learning. Qarwa, Malta, 28-30 June 2005.

[6] Cowie, C. (2000, July). Gender language: Interruption and overlapping. Paper presented at Seminar, cross-cultural pragmatics of English.

[7] Harré, R. et. al. (2009) Recent advances in Positioning Theory. Theory and Psychology, 19(1), 5-31.

[8] Herrick J.W (1999). "And Then She Said": office stories and what they tell us about gender in the workplace. Journal of Business and Technical Communication, 3(3), 274-296.

[9] Holmes, J. (1990). Hedges and boosters in women. Language \& Communication, 10(3), 185-205.

[10] Hook, D. (2007). Foucault, psychology and the analytics of power. Hampshire, England: Macmillan Distribution Ltd.

[11] Lovorn M., et. al (2012). Who's in control? teachers from five countries on power dynamics in learning environment. Journal of Research in International Education, 11 (1), 70-86.

[12] McGinty, M. S. (2001). Power Talk: Using Language To Build Authority and Influence. New York: Warner Business Books.

[13] Nemeti, A., \& Bayer, J. M. (2007). Gender differences in the use of linguistic forms in the speech of men and women: A comparative study of persian and english. Suagm.Edu, 185-201. 
[14] Newman et al (2008). Gender differences in language use: An analysis of 14,000 text samples. Discourse Processes, (45), 211-236.

[15] Rangkuti, R., \& Lubis, A. P. (2018, April 18). $1^{\text {st }}$ Annual International Conference on Language and Literature. Retrieved March 02, 2019, from http://aicll.sastra.uisu.ac. id/index.php/aicll/article/view/34/34

[16] Robinson, M., Frost, D., Buccigrossi, J., \& Pfeffer, C. (2003). Gender: Power and privilege. Retrieved from http://www.consumerstar.org/resources/pdf/Gender_4.pdf

[17] Vine, B. (2004) Getting Things Done at Work: The Discourse of Power in Workplace Interaction. Amsterdam: John Benjamins.

[18] Xu, L. (2010). Power adjustment in professional women's language: an investigation into the use of directives in the TV series Cashmere Mafia. 